Article

\title{
Investigation of the Use of Recycled Concrete Aggregates Originating from a Single Ready-Mix Concrete Plant
}

\author{
Eleftherios Anastasiou *(D), Michail Papachristoforou, Dimitrios Anesiadis, \\ Konstantinos Zafeiridis and Eirini-Chrysanthi Tsardaka
}

Laboratory of Building Materials, Department of Civil Engineering, Aristotle University of Thessaloniki, 54124 Thessaloniki, Greece; papchr@civil.auth.gr (M.P.); d.anesiadis@gmail.com (D.A.);

konzafi@gmail.com (K.Z.); extsardaka@gmail.com (E.-C.T.)

* Correspondence: elan@civil.auth.gr; Tel.: +30-2310-995787

Received: 2 October 2018; Accepted: 31 October 2018; Published: 3 November 2018

Featured Application: Recycling of the major by-products from a ready-mix concrete plant within the plant as concrete aggregates.

\begin{abstract}
The waste produced from ready-mixed concrete (RMC) industries poses an environmental challenge regarding recycling. Three different waste products form RMC plants were investigated for use as recycled aggregates in construction applications. Crushed hardened concrete from test specimens of at least $40 \mathrm{MPa}$ compressive strength (HR) and crushed hardened concrete from returned concrete $(\mathrm{CR})$ were tested for their suitability as concrete aggregates and then used as fine and coarse aggregate in new concrete mixtures. In addition, cement sludge fines (CSF) originating from the washing of concrete trucks were tested for their properties as filler for construction applications. Then, CSF was used at $10 \%$ and $20 \%$ replacement rates as a cement replacement for mortar production and as an additive for soil stabilization. The results show that, although there is some reduction in the properties of the resulting concrete, both HR and CR can be considered good-quality recycled aggregates, especially when the coarse fraction is used. Furthermore, HR performs considerably better than CR both as coarse and as fine aggregate. CSF seems to be a fine material with good properties as a filler, provided that it is properly crushed and sieved through a $75 \mu \mathrm{m}$ sieve.
\end{abstract}

Keywords: ready-mixed concrete; recycled concrete aggregates; returned concrete; concrete sludge fines; soil stabilization

\section{Introduction}

The construction industry has put considerable effort over the past years into becoming more sustainable [1]. The sustainability efforts of the industry involve practices such as energy conservation, waste minimization, and recycling. These practices apply to all aspects of construction activity, including cement and concrete production, and one important sector of concrete production is ready-mixed concrete. It is estimated that ready-mixed concrete production accounts for 350 million tons per year in the EU in 2016 [2], and the waste associated with this production varies greatly depending on local construction practices and is estimated at about $0.5-2 \%$ of the total production [3]. The waste streams generated from the ready-mix concrete plants (RMC) also vary, depending on the waste management strategies employed. The literature indicates several waste management strategies for RMC plants: some strategies include the use of the washing-out process for reclaiming the aggregates from the fresh concrete returns [4], the direct use of the fresh concrete returns in downgraded concrete products [5], and water reclamation by pressuring the sedimentation tanks [6]. 
The main solid wastes generated from RMC are hardened concrete from trial mixes or concrete testing, returned fresh concrete, and sludge fines from the washing of trucks. All of these materials could be used, potentially, in new construction products as recycled aggregates [7-9].

The use of recycled aggregates in concrete is of paramount importance for the sustainability of the construction industry, either seen from the point of view of natural resource scarcity [10] or from the point of view of waste and landfilling minimization [11]. As in most recycling processes, it is not an easy task; recycled aggregates originate from various sources and their quality level is not guaranteed [12]. Typically, they have inferior properties compared to natural aggregates $[13,14]$ and, furthermore, they pose some technical difficulties (contaminants, higher absorption, etc.) $[15,16]$. However, a great number of researchers have explored the possibilities of using recycled aggregates in concrete in a beneficial way, either by suggesting ways of upgrading the product [17-20] or by categorizing and directing the proper quality of recycling aggregates to a suitable application [21-23].

The present report focuses on three main waste products from RMC, in the form of recycled aggregates from hardened good quality concrete (HR), recycled aggregates from hardened fresh concrete returns (CR), and recycled cement sludge fines from the washing of the concrete trucks (CSF). HR was produced by crushing test concrete specimens, typically used in the quality control of RMC concrete batches. In order to have a good-quality recycled aggregate, concrete specimens with an original compressive strength of $40 \mathrm{MPa}$ or higher were selected for crushing, as it is shown from the literature that the original strength of the concrete influences the properties of the recycled aggregate and of the new concrete [24,25]. CR was also produced from crushing hardened concrete; however, prior to unloading the trucks, it is common that a considerable amount of water is used to ease the placing process. Therefore, $\mathrm{CR}$ originated from a lower-strength concrete than HR and was expected to be of lower quality. Kou et al. (2012) suggest that CR aggregates should be used in concrete mixtures with a w/c ratio as low as 0.35 . HR and CR were tested for their suitability as concrete aggregates before substituting natural aggregates in test concrete mixtures. CSF has been found to consist mostly of hardened and unhydrated cement grain and fine aggregate [26]. It is a fine material which can be easily ground and sieved to a small size and has the potential to be used as a construction material [27].

In the present report, HR and CR were considered as recycled concrete aggregates (both coarse and fine) and were tested in concrete mixtures. On the other hand, CSF was considered as a filler and was tested separately. Following an investigation on the use of similar fine materials [28-30], and after investigating its physicochemical properties, CSF was tested in the present research as a material for soil stabilization at a $10 \%$ and $20 \%$ addition rate and as a filler, substituting 10 and $20 \mathrm{wt} \%$. of cement in mortars.

The recycled aggregates from RMC have the benefit of being recycled concrete aggregates (RCA) without any mixed construction and demolition waste inclusions, which renders them acceptable for many standards regarding the use of RCA in concrete [31]. In addition, if they can be recycled on-site in new concrete products, then two other benefits compared to other RCAs arise; they are expected to have less fluctuation in properties compared to RCA from various sources, and there are no transportation costs. The pretreatment required for such aggregates (drying, crushing, sieving and soaking) can easily be carried out within the RMC plant [32,33]. Therefore, the recycling of considerable amounts of RMC waste would render the plant more sustainable and environmentally friendly.

\section{Materials and Methods}

\subsection{Recycled Concrete Aggregates (HR and CR)}

Crushed limestone (L) was used as a reference aggregate, as it is the most common aggregate used in concrete production in Greece. Fresh concrete returns (CR) and recycled concrete of high compressive strength (HR) were crushed and sieved in order to achieve the same gradation as limestone aggregates.

The recycled aggregates (HR and CR) were used as natural coarse aggregate replacements or as both fine and coarse aggregate replacements in concrete mixtures. The different fractions of recycled 
aggregates were examined separately since they typically have different properties, such as different water absorption and different amounts of adhered mortar [34-36]. The replacement ratio of either the fine or coarse fraction was selected to be $100 \%$, in order to determine clearly the effect of aggregate substitution on the properties of the new concrete, although the optimum replacement ratio is usually less than $100 \%[37,38]$. The aggregates under investigation were tested for their physical and chemical suitability for use in concrete, as well as for their durability.

\subsubsection{Recycled Aggregate Properties Testing}

The aggregate tests that were conducted were the sand equivalent test according to EN 933-8 and methylene blue test according to EN 933-9, in order to determine the quantity and quality of their fines. Grain size distribution was measured according to EN 933-2, in order to simulate similar aggregate gradation to that of the natural aggregates. Density (bulk, dry, saturated surface dry) and water absorption for the saturated-surface dry (SSD) condition were determined in order to perform the concrete mix design. Since water absorption for the recycled aggregates is usually higher than that of natural aggregates, the recycled aggregates were used in the SSD condition in order to have the same effective $\mathrm{w} / \mathrm{c}$ ration in all mixtures. X-ray diffraction analysis (XRD) was used for the determination of the mineralogical composition, with a PW 1840 Phillips diffractometer (Philips, Amsterdam, Netherlands) and Ionic Chromatography for the determination of the water-soluble sulfate salts content $\left(\mathrm{SO}_{3} \mathrm{wt} \%\right.$ ), with Dionex CS-1100, Thermoscientific Instruments (ThermoFisher Scientific, Waltham, USA). Regarding the assessment of the durability of the recycled aggregates, two tests were carried out: resistance to fragmentation (Los Angeles test) according to EN 1097-2 and resistance to freezing and thawing according to EN 1367-1.

\subsubsection{Design of Concrete Mixtures}

Five concrete mixtures were prepared in the laboratory and their terminology is given in Table 1. The reference concrete mixture with limestone aggregates (LL) was a standard C25/30 mixture with maximum aggregate size of $16 \mathrm{~mm}$. All concrete mixtures were produced using $300 \mathrm{~kg} / \mathrm{m}^{3}$ cement CEM II32.5, 0.55 effective water/cement ratio and $1.5 \mathrm{~kg} / \mathrm{m}^{3}$ superplasticizer. Limestone coarse aggregates (4-16 mm fractions) were replaced in mixtures CR55 and HR55 by CR and HR aggregates, respectively. The total amount of aggregates in mixtures CR100 and HR100 consisted of CR and HR, respectively. All the aggregates were added in a saturated-surface-dry condition by estimating the water absorbed by the aggregates and pre-soaking them. Each fraction of each gradation (i.e., $0.25-0.50 \mathrm{~mm}, 0.50-1.00 \mathrm{~mm}$, etc.) was separately sieved for the three aggregate types used, so that the aggregate gradation curve would be the same for all mixtures. These particle-size distribution curves are shown in Figure 1. The final proportions of all mixtures are presented in Table 2. All specimens cast were cured at $20{ }^{\circ} \mathrm{C}$ and $95 \% \mathrm{RH}$ until testing.

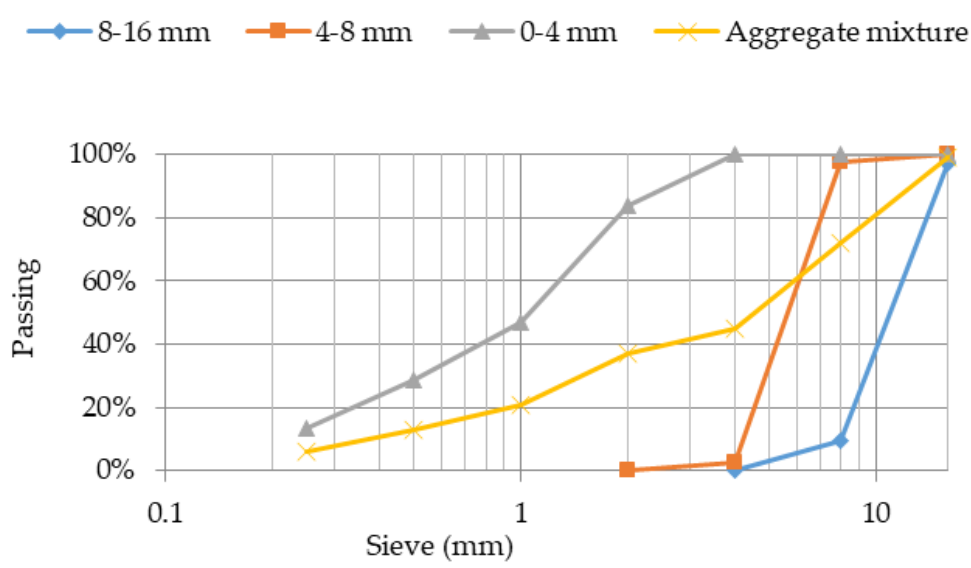

Figure 1. Particle size distribution and aggregate mix gradation curve for all test mixtures. 
Table 1. Terminology for all concrete mixtures.

\begin{tabular}{cl}
\hline Mixture & \multicolumn{1}{c}{ Designation } \\
\hline LL & Reference (100\% of aggregates limestone) \\
CR55 & Recycled fresh concrete returns as coarse aggregates \\
CR100 & $100 \%$ of aggregates recycled fresh concrete returns \\
HR55 & Recycled concrete of high compressive strength as coarse aggregates \\
HR100 & $100 \%$ of aggregates recycled concrete of high compressive strength \\
\hline
\end{tabular}

Table 2. Proportions of all mixtures in $\mathrm{kg} / \mathrm{m}^{3}$.

\begin{tabular}{lccccc}
\hline Concrete Composition & LL & CR55 & CR100 & HR55 & HR100 \\
\hline Cement CEM II32.5 & 300 & 300 & 300 & 300 & 300 \\
Tap water & 165 & 165 & 165 & 165 & 165 \\
Fine aggregate 0-4 mm & 842 & 843 & 528 & 843 & 499 \\
Coarse aggregate 4-8 mm & 478 & 478 & 300 & 478 & 283 \\
Coarse aggregate 8-16 mm & 576 & 525 & 525 & 542 & 542 \\
Superplasticizer & 1.5 & 1.5 & 1.5 & 1.5 & 1.5 \\
\hline
\end{tabular}

\subsubsection{Fresh and Hardened Concrete Testing}

In order to assess the fresh properties of the test mixtures, the air content, bulk density and consistency by the slump test of fresh concrete were measured according to EN 12350. Hardened concrete was tested for its mechanical properties and durability with the following tests:

- Open porosity according to RILEM CPC11.3 in water under vacuum;

- Seven and 28-day compressive strength test in $150 \mathrm{~mm}$ cubes (at least three for each testing age and mix);

- Elastic modulus in $150 \times 300 \mathrm{~mm}$ cylinders (at least three for each testing age and mix);

- Three-point bending strength in $100 \times 100 \times 400 \mathrm{~mm}$ prisms (at least three for each testing age and mix);

- Drying shrinkage by $100 \times 100 \times 1000 \mathrm{~mm}$, cured in $20^{\circ} \mathrm{C}$ and $<50 \% \mathrm{RH}$;

- Resistance to chloride ion penetration according to ASTM C 1202-97;

- Freeze-thaw resistance with de-icing salts after 10 cycles according to CEN/TS 12390-9.

\subsection{Cement Sludge Fines (CSF)}

Cement sludge fines (CSF) were obtained from the same RMC plant as the recycled aggregates, in wet condition. Figures 2 and 3 show the sedimentation tanks and the storage of CSF in the RMC plant, while Figure 4 shows the CSF as received. The measured moisture in CSF was $42 \%$ and, therefore, it was left to dry in laboratory conditions for 2-3 days and then oven-dried at $100{ }^{\circ} \mathrm{C}$ until a constant mass was reached. After drying, it was crushed and sieved in order to obtain a fine material passing from the $75 \mu \mathrm{m}$ sieve. The chemical composition of CSF and of the reference CEM I42.5 cement used were determined using atomic absorption spectroscopy, AAnalyst 400, Perkin Elmer. Additionally, their water-soluble salts were determined using ionic chromatography, Dionex, while simultaneous DTA-TGA (differential thermal-thermogravimetric analysis), SDT 2960 TA Instruments, was used for the determination of the calcium carbonate $\left(\mathrm{CaCO}_{3}\right)$ content of $\mathrm{CSF}$, under an $\mathrm{N}_{2}$ atmosphere from $10^{\circ} \mathrm{C}$ to $1000^{\circ} \mathrm{C}$. The particle size distribution of CSF was determined with a Malvern Mastersizer 2000 analyzer. Furthermore, strength activity tests with lime according to ASTM C593-95 were performed, in order to determine its potential pozzolanicity. 


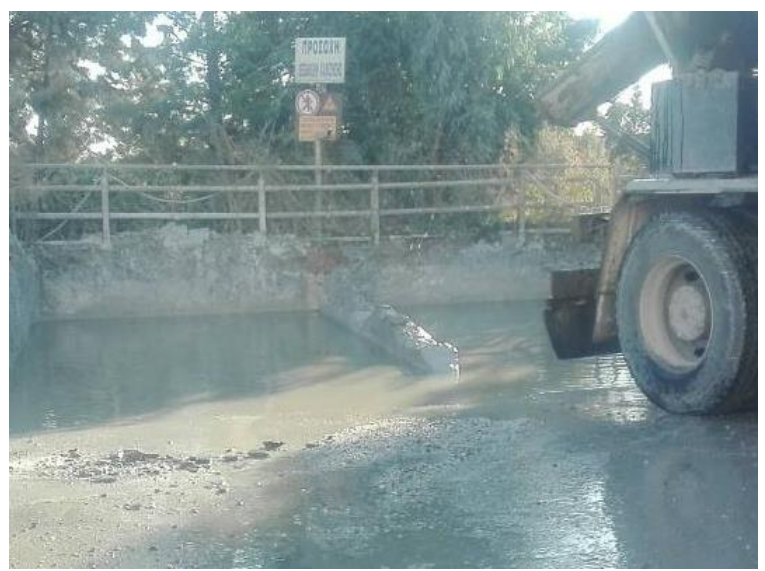

Figure 2. Sedimentation tank for the water-washing of the trucks.

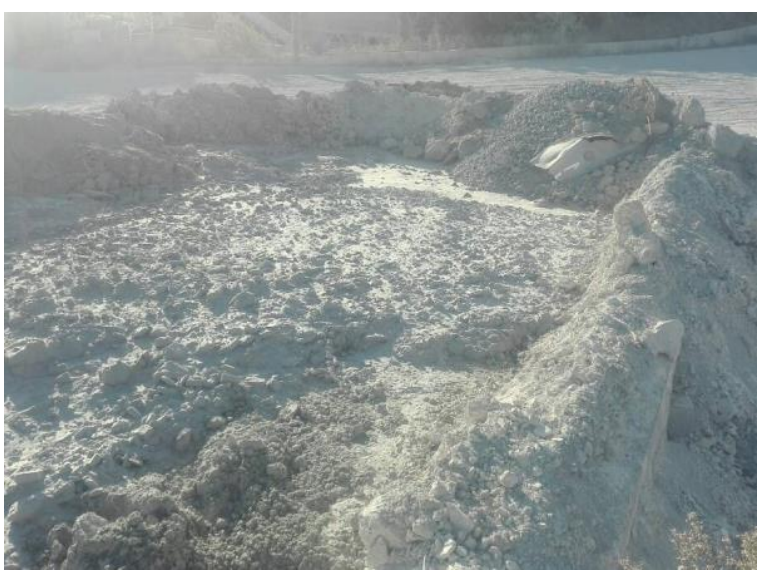

Figure 3. Stockpiled cement sludge fines (CSF) within the ready-mixed concrete (RMC) plant.

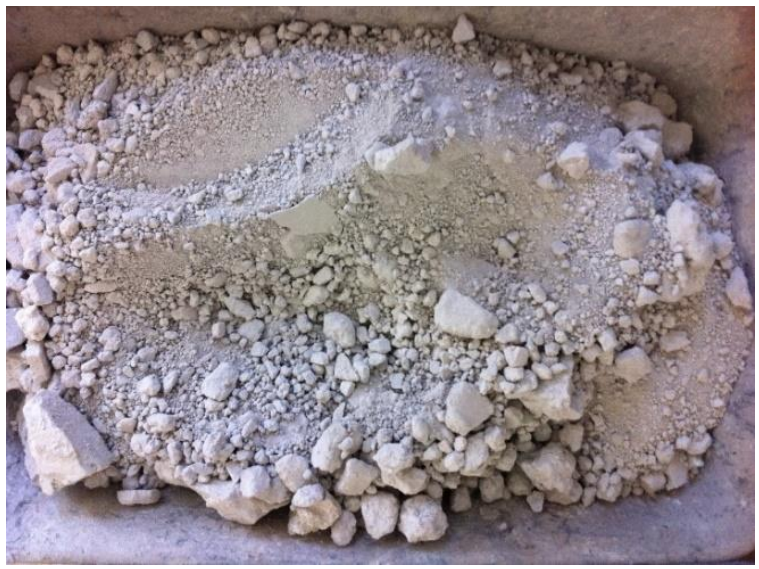

Figure 4. CSF as received (with $42 \%$ moisture content).

\subsubsection{CSF as a Replacement of Cement in Mortars}

CSF was considered as a filler material and it was used as 10 and $20 \mathrm{wt} \%$. Portland cement CEM I 42.5 replacement in mortars. All mixtures were prepared using a cement/siliceous river sand ratio of 0.33 and a water/binder ratio of 0.50 . The fresh mortars were tested for bulk density and consistency and were cured at $20{ }^{\circ} \mathrm{C}$ and $95 \% \mathrm{RH}$ until testing. Compressive strength was measured in $40 \times 40 \times 40 \mathrm{~mm}$ cubes (at least three for each testing age and mix) at ages of 3, 7 and 28 days. Additionally, X-ray diffraction analysis (XRD) was used for the determination of the mineralogical 
composition of the mortar with $20 \% \mathrm{CSF}$, and the porosity of hardened mortars was measured according to RILEM CPC11.3 in water under vacuum, after the completion of 28 days.

\subsubsection{CSF as an Additive for Soil Stabilization}

A well-known use of filler materials is for the improvement of poor soils, and CSF was also tested as an additive for soil stabilization. A sample of a low-quality reference soil with a $5 \%$ California Bearing Ratio (CBR) value was taken from a metro station excavation site in Thessaloniki, Greece. Two addition rates of CSF in soil were examined: 10 and $20 \mathrm{wt} \%$. The maximum dry density and optimum moisture content according to the modified Proctor test and the CBR coefficient of soils were measured and compared.

\section{Results and Discussion}

\subsection{Recycled Concrete Aggregates (HR and CR)}

\subsubsection{Recycled Aggregate Test Results}

With the sand equivalent test, the calculation of SE value gives an estimation of the percentage of fines (aggregate particles that pass the $0.063 \mathrm{~mm}$ sieve). For higher SE values, the percentage of fines decreases. The results of the test are given in Figure 5. The higher concentration of fines was observed for $\mathrm{CR}$, which can be explained by the high w/c ratio of concrete returns, which reduces the mechanical properties of the cement paste attached on the aggregates and thus produces more fines during crushing. On the other hand, in HR aggregates, the fines concentration is relatively low since the hardened cement paste is of high strength.

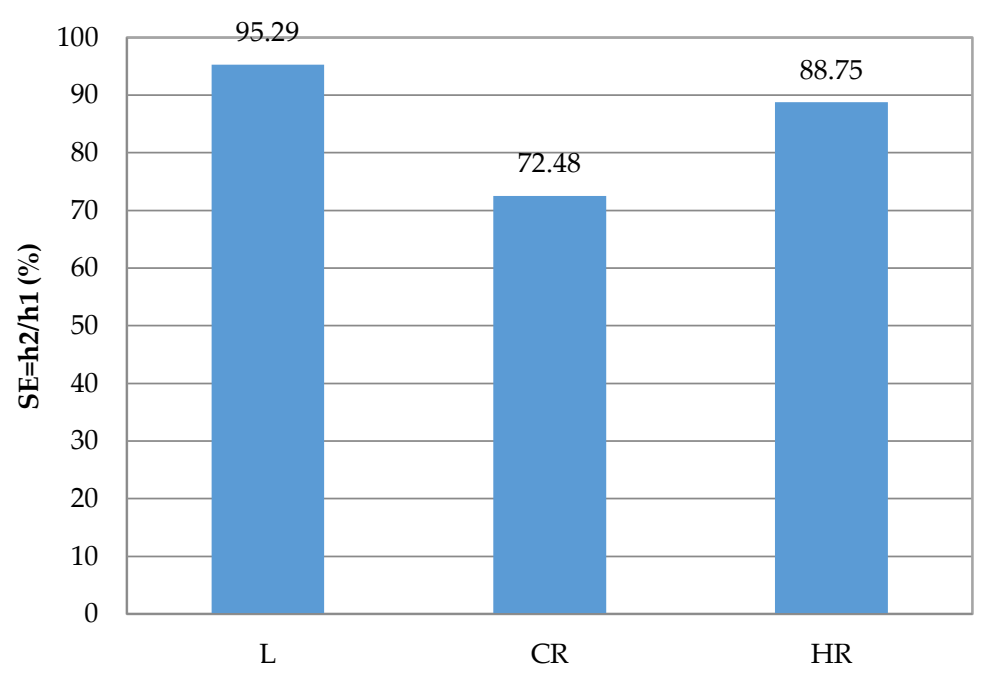

Figure 5. Results of sand equivalent test. L: crushed limestone; CR: crushed hardened concrete from returned concrete; HR: crushed hardened concrete from test specimens of at least $40 \mathrm{MPa}$ compressive strength.

After identifying the content of fines in the recycled aggregates, it was considered necessary to determine if any clay particles exist in these fines and also measure the particle size distribution of aggregates. The results of the methylene blue test that was conducted for this purpose can be seen in Figure 6. It was observed that, for CR aggregates, a higher amount of injected dye solution is required, which is an indication of clay concentration. On the contrary, the concentration of clay in HR fines is insignificant. Since CR is $100 \%$ recycled concrete, the existence of clay can be attributed to storing and handling these aggregates in the facility of RMC. 


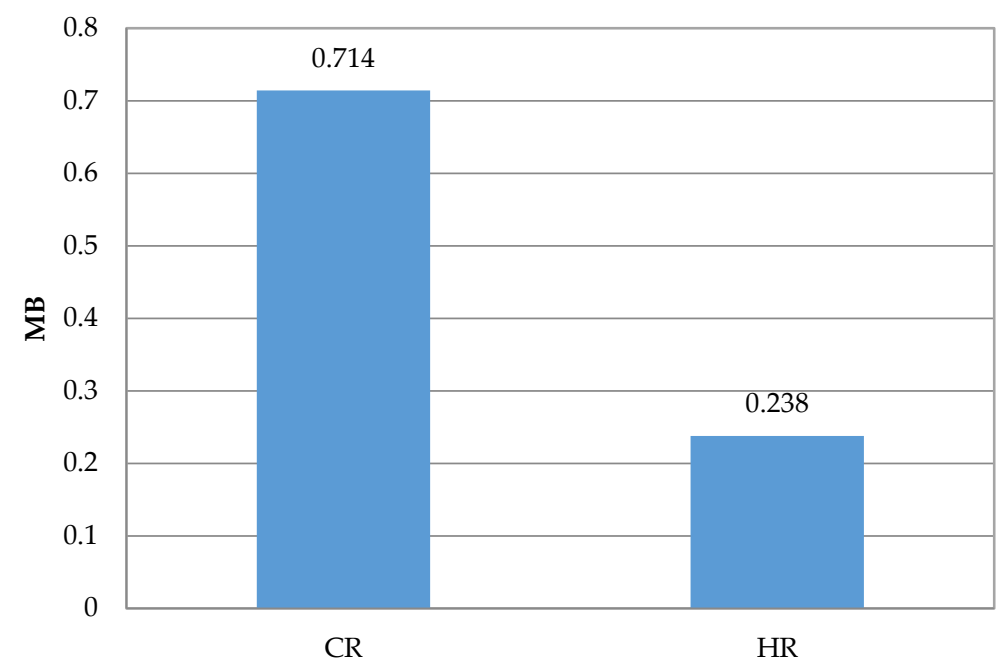

Figure 6. Results of methylene blue test.

Table 3 shows the results of water absorption $\left(\mathrm{WA}_{24}\right)$, particle bulk density $\left(\mathrm{p}_{\mathrm{a}}\right)$, particle dry density ( $\left.p_{\text {rd }}\right)$, particle saturated-surface-dry density $\left(\mathrm{p}_{\mathrm{ssd}}\right)$ and Los Angeles coefficient (LA) tests. CR seems to absorb more water compared to HR, which is an indication of lower quality. However, the densities of the two aggregates do not differ essentially. The LA coefficient of CR was lower, but comparable to $\mathrm{HR}$, and both aggregates have acceptable resistance to fragmentation according to the EN 12620 categorization. The mineralogical compositions of the raw materials CR and HR are given in Figures 7 and 8 . The presence of calcite and quartz in both materials is related to the binder attached on the aggregates, as well as tri-calcium-silicate compounds $\left(C_{3} S\right)$ traces. The $C_{3} S$ in $C R$ was attributed to unhydrated forms of cement. Additionally, portlandite content $(\mathrm{P})$ originating from the hydration of cement paste was found in HR.

Table 3. Aggregate test results.

\begin{tabular}{ccccc}
\hline & CR Fine & CR Coarse & HR Fine & HR Coarse \\
\hline WA24 $(\%)$ & 6.13 & 5.45 & 5.88 & 3.21 \\
$\mathrm{pa}_{\mathrm{a}}\left(\mathrm{kg} / \mathrm{m}^{3}\right)$ & 1723 & 2604 & 1617 & 2610 \\
$\mathrm{p}$ rd $\left(\mathrm{kg} / \mathrm{m}^{3}\right)$ & 1558 & 2281 & 1477 & 2409 \\
$\mathrm{p}$ & 1654 & 2405 & 1563 & 2486 \\
$\mathrm{LA}$ & - & $31.1 \%$ & - & $36.5 \%$ \\
\hline
\end{tabular}

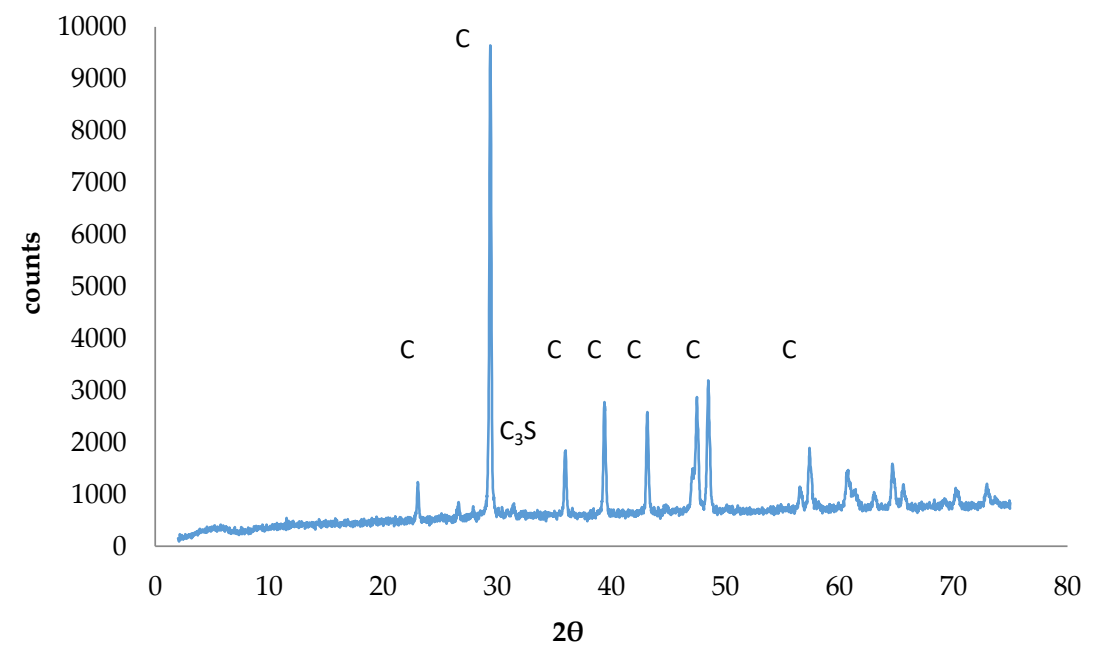

Figure 7. XRD diagram of $C R$, where $C$ : calcite, $Q$ : quartz and traces of $C_{3} S$. 


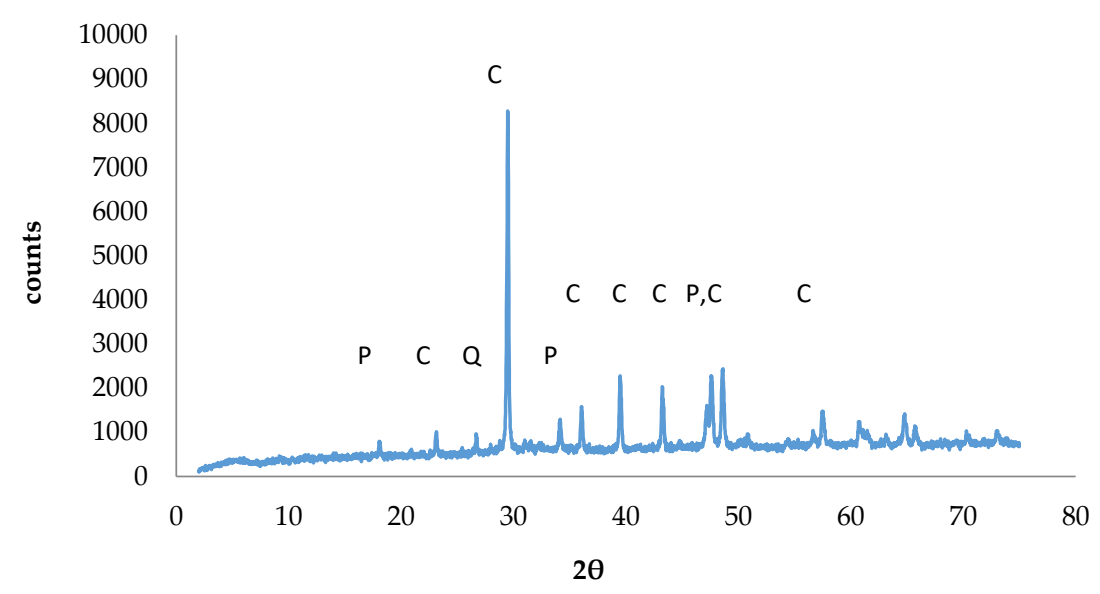

Figure 8. XRD diagram of $H R$, where C: calcite, Q: quartz and P: portlandite.

The durability test results for $\mathrm{CR}$ and HR regarding mass loss (wt \%) after 10 cycles of freezing-thawing are given in Figure 9. HR aggregates showed better results compared to CR. The mass loss of both aggregates is less than the upper category limit of 40\% according to EN 12620 .

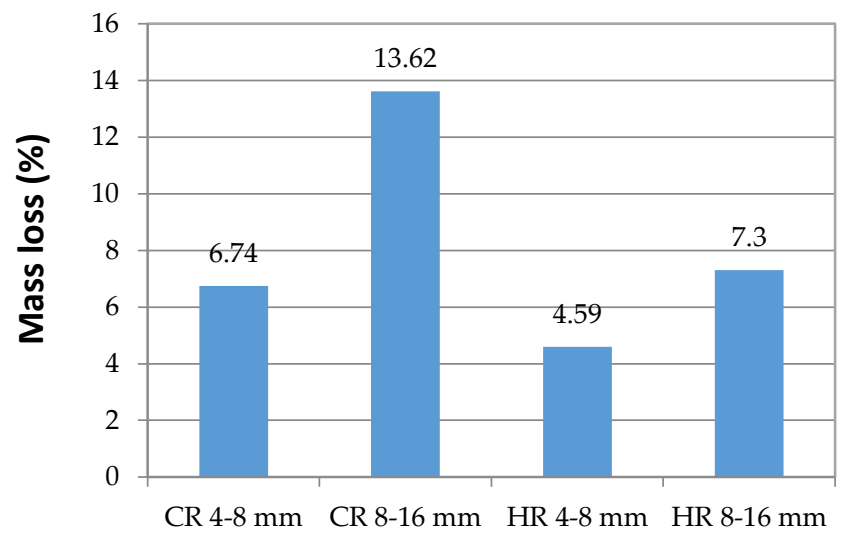

Figure 9. Resistance to freezing and thawing expressed by mass loss.

The sieved representative samples $(<0.75 \mathrm{~mm})$ of CR and HR were collected in order to quantify their water-soluble sulfate salts, utilizing ionic chromatography. Sulfate salts were found in a low proportion in the mate and HR, respectively.

Although both CR and HR originate from hardened concrete, with a recycled concrete content of $90 \%$ or higher, it seems clear that HR is a higher quality aggregate, as expressed by the water absorption values, the fines quality characterization and the durability testing.

\subsubsection{Concrete Test Results}

The results of the fresh concrete tests are shown in Table 4. Slump values increased as the rate of recycled aggregate increased, which can be attributed to the method of achieving the SSD condition of the aggregates, with HR aggregates showing better results. The recycled aggregates have been soaked with the amount of water required to reach the SSD state; however, it is not certain if the aggregates have actually absorbed all the water in the presoaking process or if they produced free water during the mixing process, mainly due to their porous nature. It is very probable that they did not remain completely saturated and that an amount of free water was released from the aggregates, resulting in an increased $\mathrm{w} / \mathrm{c}$ ratio and increased workability. Of course, there is a reduction in the strength of the concrete with recycled aggregates, which is attributable to this excess water. The air content of all mixtures was around $2 \%$, regardless of the type of aggregates used. The density seemed to decrease as 
the rate of recycled aggregates in the mixture increased, but the reduction is greater, as expected, when the fine recycled aggregates are used.

Table 4. Fresh concrete properties.

\begin{tabular}{cccccc}
\hline & LL & CR55 & CR100 & HR55 & HR100 \\
\hline Air content $(\%)$ & 2 & 2 & 2.3 & 2.2 & 2 \\
Slump $(\mathrm{cm})$ & 6.5 & 11 & 17 & 15 & 18 \\
Density $\left(\mathrm{kg} / \mathrm{m}^{3}\right)$ & 2418 & 2318 & 2165 & 2378 & 2157 \\
\hline
\end{tabular}

The results of the tests that were conducted on hardened concrete are given in Table 5, while in Figure 10, various mechanical properties of the recycled-base mixtures $\left(\mathrm{Xi}_{\mathrm{i}}\right)$ are compared to the corresponding ones of reference concrete $\left(\mathrm{X}_{\mathrm{LL}}\right)$. HR-based mixtures showed increased mechanical properties compared to those with $\mathrm{CR}$ aggregates and were lower compared to reference concrete. The open porosity was similar to that of the reference concrete when coarse recycled aggregates were used, but it increased considerably when the fine recycled aggregate was used. Compared to LL, HR 55 and HR100 showed a reduction of compressive strength of only $11 \%$ and $15 \%$, respectively, which indicates that even the finer fraction of HR does not reduce the compressive strength of the produced concrete considerably. The flexural strength and elastic modulus, on the other hand, rely more on the quality of the interfacial transition zone between the aggregate and the cement paste, and the reduction in these values is in the range of $9-13 \%$ and $28-38 \%$ for HR55 and HR100, respectively. This implies that the bond between the fine aggregates and the cement paste was weaker when fine HR was used. Regarding CR, however, CR 55 and CR100 showed a reduction of compressive strength by $26 \%$ and $47 \%$, respectively, which corresponds with the lower properties of CR measured earlier and the same trend applied for flexural strength and elastic modulus.

Table 5. Hardened concrete tests.

\begin{tabular}{|c|c|c|c|c|c|c|}
\hline & & LL & CR55 & CR100 & HR55 & HR100 \\
\hline \multicolumn{2}{|l|}{ Open porosity (\%) } & 13 & 11 & 21 & 10 & 22 \\
\hline \multirow{2}{*}{$\begin{array}{l}\text { Compressive strength } \\
(\mathrm{MPa})\end{array}$} & 7-day & 33 & 22 & 18 & 28 & 27 \\
\hline & 28-day & 38 & 28 & 20 & 34 & 33 \\
\hline \multicolumn{2}{|c|}{ 28-day flexural strength (MPa) } & 7.03 & 5.36 & 4.87 & 6.10 & 5.05 \\
\hline \multicolumn{2}{|c|}{ 28-day elastic Modulus (GPa) } & 44.7 & 40.2 & 25.3 & 40.8 & 27.6 \\
\hline \multicolumn{2}{|c|}{ 28-day drying shrinkage ( $\mu$ strain) } & 180 & 400 & 590 & 220 & 300 \\
\hline Resistance to chloride & Charge passed & 2491 & 3912 & 8284 & 2913 & 9342 \\
\hline Ion penetration & Chloride ion penetrability & MODERATE & MODERATE & $\mathrm{HIGH}$ & MODERATE & $\mathrm{HIGH}$ \\
\hline \multicolumn{2}{|c|}{ Freeze-thaw mass loss (wt \%) } & 0.422 & 0.362 & 0.845 & 0.412 & 0.890 \\
\hline
\end{tabular}

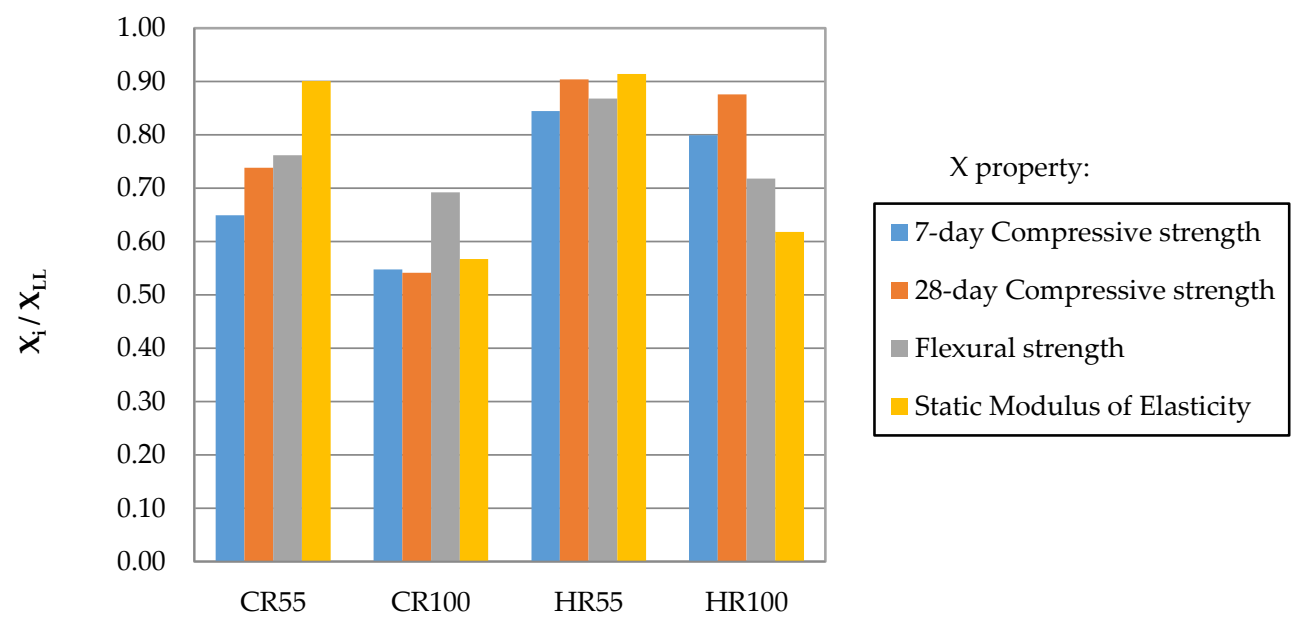

Figure 10. Comparison of various properties of mixtures $(X)$ with the reference concrete $\left(X_{L L}\right)$. 
Regarding the durability tests, as shown in Table 5, the concretes with coarse CR and HR showed similar chloride ion penetrability to the reference concrete, while the mixtures with both fine and coarse recycled aggregates showed considerably higher penetrability. This can be attributed to the increased porosity of CR100 and HR100, which allowed the chloride ions to enter the concrete mass. Freeze-thaw results serve only as an indication of durability, since more cycles are usually required; however, the tested concretes with only coarse recycled aggregates seem to perform in a similar way to the reference concrete. The drying shrinkage results, as shown in Figure 11, show that HR aggregates, regardless of size, perform better than CR aggregates. In particular, concrete HR55 was closer to the reference concrete, while CR100 showed a distinct increase in shrinkage and, hence, reduced durability, which corresponds to the previous tests.

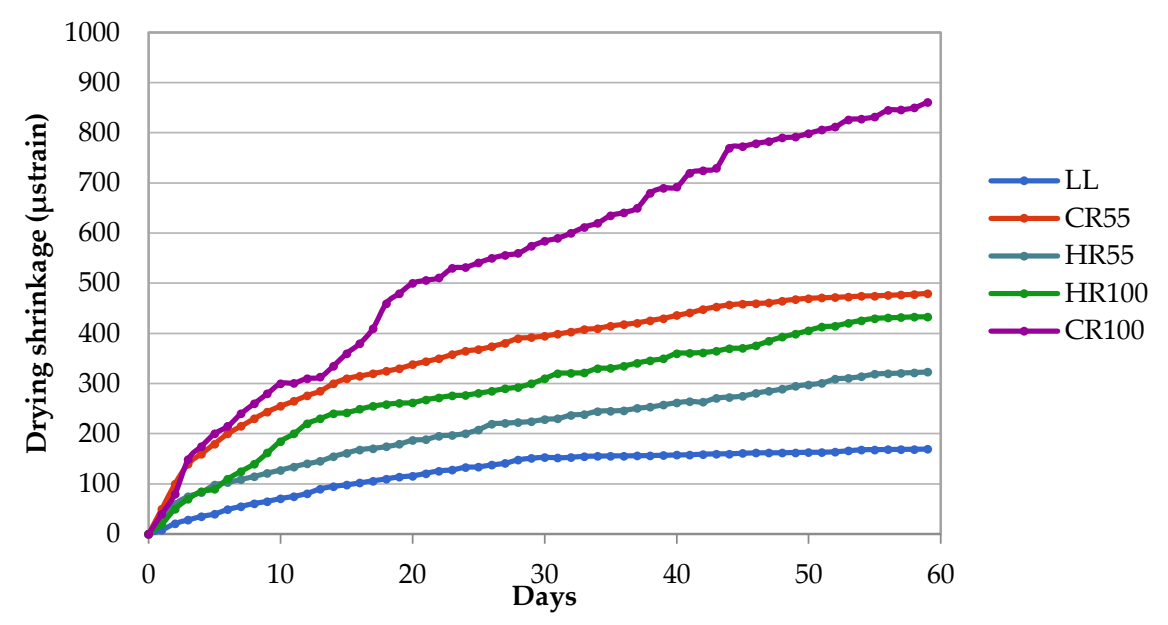

Figure 11. Drying shrinkage of test concretes.

In general, the mechanical properties of concrete decreased as the rate of recycled aggregates increased. However, the mixtures with coarse recycled aggregates (CR55 and HR55) showed only a minimal decrease in both mechanical and durability properties when compared to the reference concrete. Furthermore, there is a clear distinction between the two types of recycled aggregates, as HR performed better than CR in all cases. In the cases of compressive strength and drying shrinkage, concrete with both fine and coarse HR showed better results than concrete with only coarse CR. These results, along with the initial test results on the materials, imply that HR aggregates are of better quality than CR aggregates and should be managed separately within the RMC plant and directed at different applications.

\subsection{Cement Sludge Fines (CSF)}

The chemical composition of the CSF, OPC (CEM I42.5 N) and soil used are shown in Table 6, while their particle size distribution in comparison to that of CEM I42.5 is shown in Figure 12. CSF consists mostly of hardened cement paste and fine limestone aggregates; therefore, its $\mathrm{CaO}$ and $\mathrm{SiO}_{2}$ contents were not expected to be reactive. The high value of loss on ignition can be attributed to the bonded water proportion and $\mathrm{CO}_{2}$ quantity that was emitted from the sample, while the DTA-TG results (Figure 13) indicated a small amount portlandite $(0.18 \mathrm{wt} \%)$ and the presence of a high amount of $\mathrm{CaCO}_{3}(67.77 \mathrm{wt} \%)$.

Table 6. Chemical composition of CSF and cement I42.5 N.

\begin{tabular}{|c|c|c|c|c|c|c|c|c|c|c|c|}
\hline (wt \%) & $\mathrm{Na}_{2} \mathrm{O}$ & $\mathrm{K}_{2} \mathrm{O}$ & $\mathrm{CaO}$ & $\mathrm{MgO}$ & $\mathrm{Fe}_{2} \mathrm{O}_{3}$ & $\mathrm{Al}_{2} \mathrm{O}_{3}$ & $\mathrm{SiO}_{2}$ & L.I.\% & $\mathrm{Cl}^{-}$ & $\mathrm{NO}_{3}{ }^{-}$ & $\mathrm{SO}_{3}$ \\
\hline CSF & 0.19 & 0.21 & 32.09 & 1.05 & 1.26 & 2.45 & 36.51 & 25.22 & 0.01 & $<0.01$ & 0.05 \\
\hline CEM I42.5 N & 0.57 & 1.08 & 66.84 & 3.91 & 2.40 & 3.74 & 19.55 & 1.91 & 0.03 & 0.02 & 1.49 \\
\hline Soil & 0.90 & 0.98 & 8.67 & 5.39 & 3.79 & 6.88 & 63.14 & 10.25 & 0.08 & 0.02 & 0.02 \\
\hline
\end{tabular}




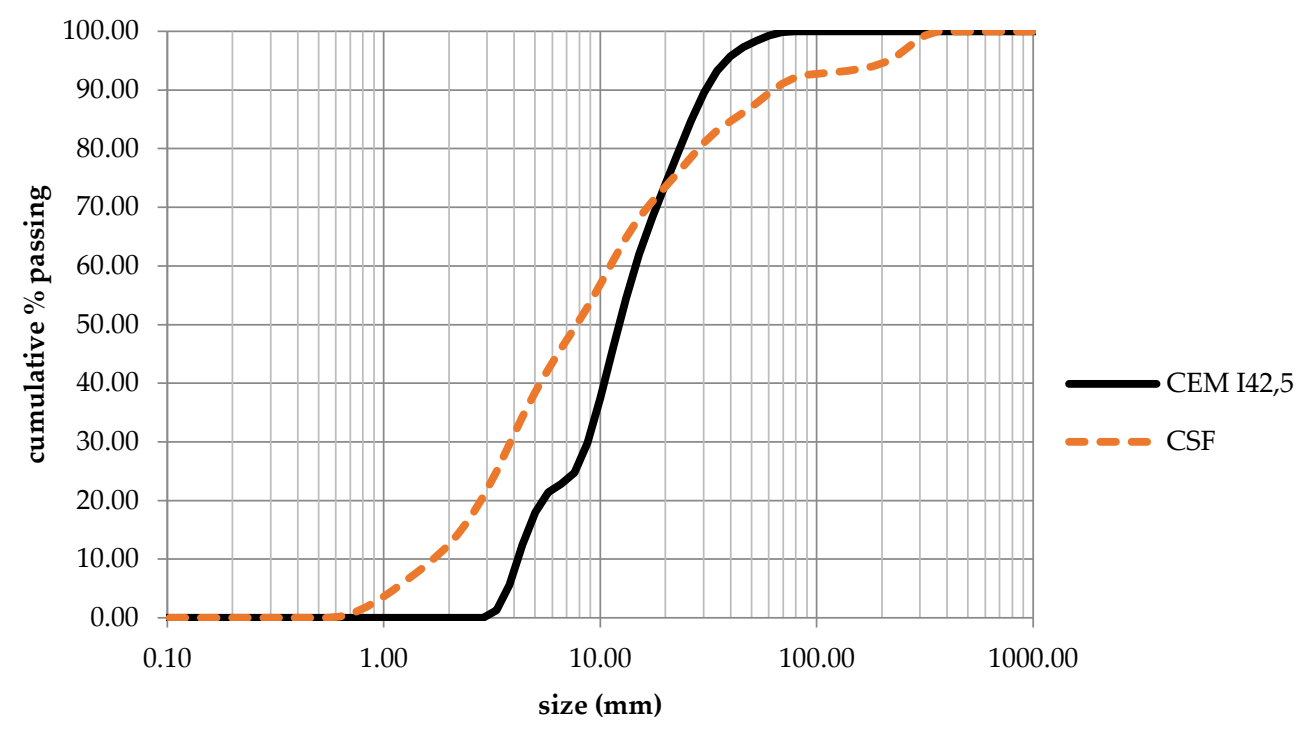

Figure 12. Particle size distribution of CSF and cement.

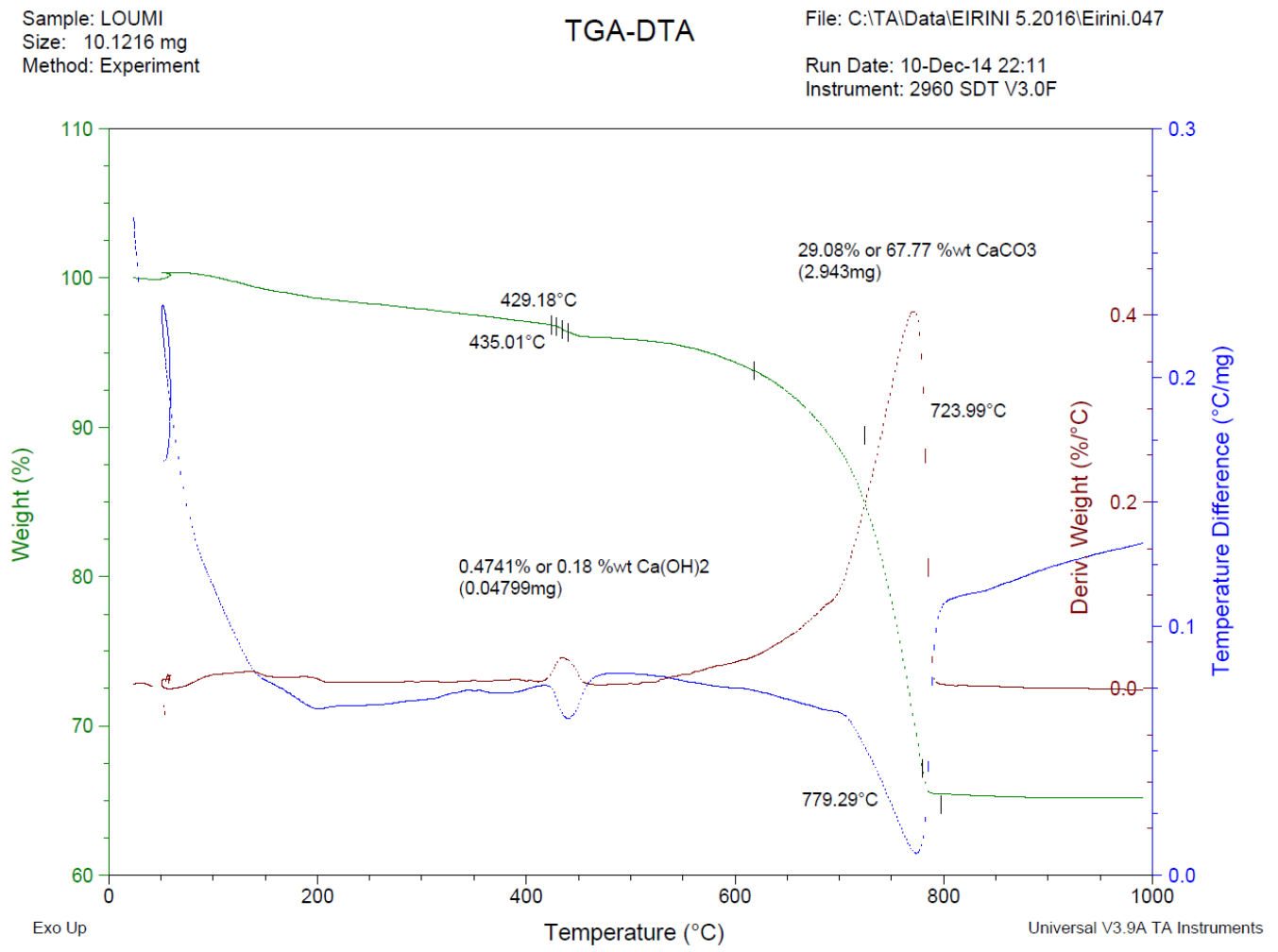

Figure 13. Differential thermal-thermogravimetric analysis (DTA-TGA) analysis of CSF and quantification of calcite content as a percentage by mass of sample.

The XRD diagram (Figure 14) shows that the mineralogical composition of CSF was mainly calcite. Also, an absence of $\mathrm{C}_{3} \mathrm{~S}$ and traces of $\mathrm{C}_{2} \mathrm{~S}$ peaks were observed. The latter may indicate full hydration of sludge. Also, a strength development test with lime according to ASTM C593-95 showed minimal strength development at 28 days $(<0.50 \mathrm{MPa})$, which implies that there is no significant pozzolanic activity from CSF. The results of the analytical tests imply that CSF is probably a fine material without any hydraulic or pozzolanic properties. The fact that it can be easily crushed and sieved through the $75 \mu \mathrm{m}$ implies that CSF could be used as a filler material. Regarding handling and processing, it would be preferable to use CSF in its original wet condition in order to avoid the drying process; however, further research is required in this direction. 


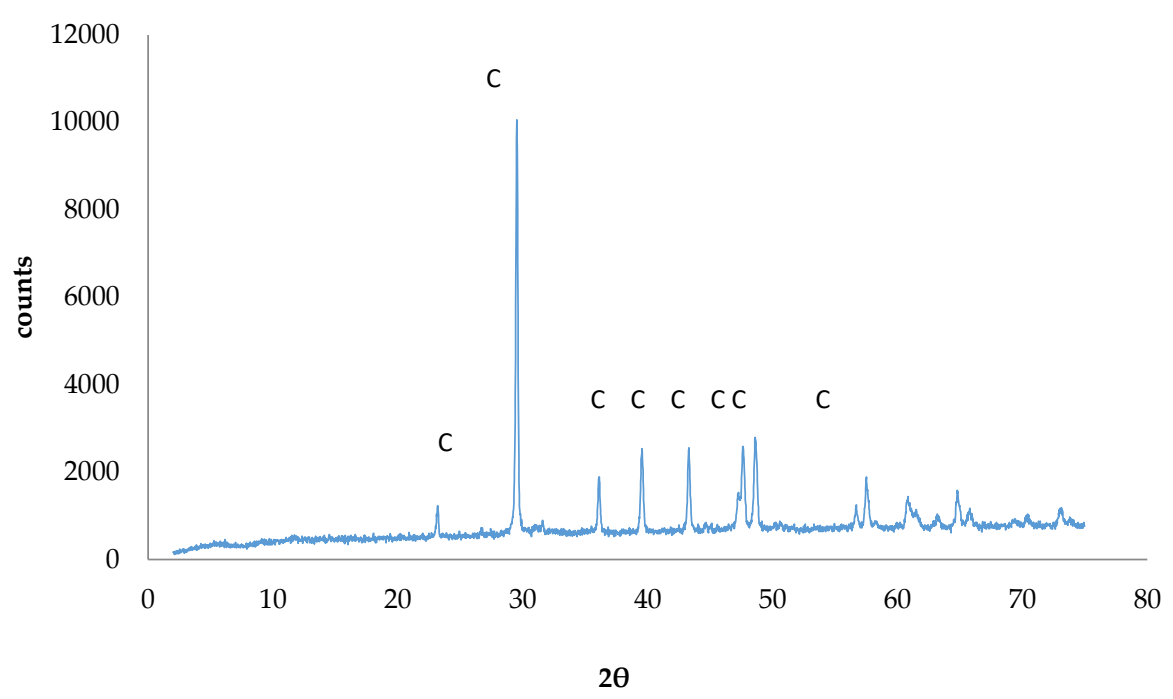

Figure 14. XRD diagram of CSF, where C: calcite.

\subsubsection{CSF as a Cement Replacement in Mortars}

The results of compressive strength testing are displayed in Figure 15. Mortar with a $10 \%$ replacement of cement by CSF reached almost the same strength levels as the reference. The early strength was slightly lower than the reference; however, the 28-day strength was slightly higher compared to reference. The mortar with $20 \%$ CSF showed a $7 \%$ reduction of strength compared to the reference. These results can be attributed to the filler effect [39], while the XRD results (Figure 16) on 28-day mortar samples with $20 \%$ CSF confirm the absence of ettringite. When a filler is added in a certain percentage, it influences the $\mathrm{pH}$ value of the binders in the pore solution. If the $\mathrm{pH}$ is reduced, this affects the hydration and as a result the compressive strength [40].

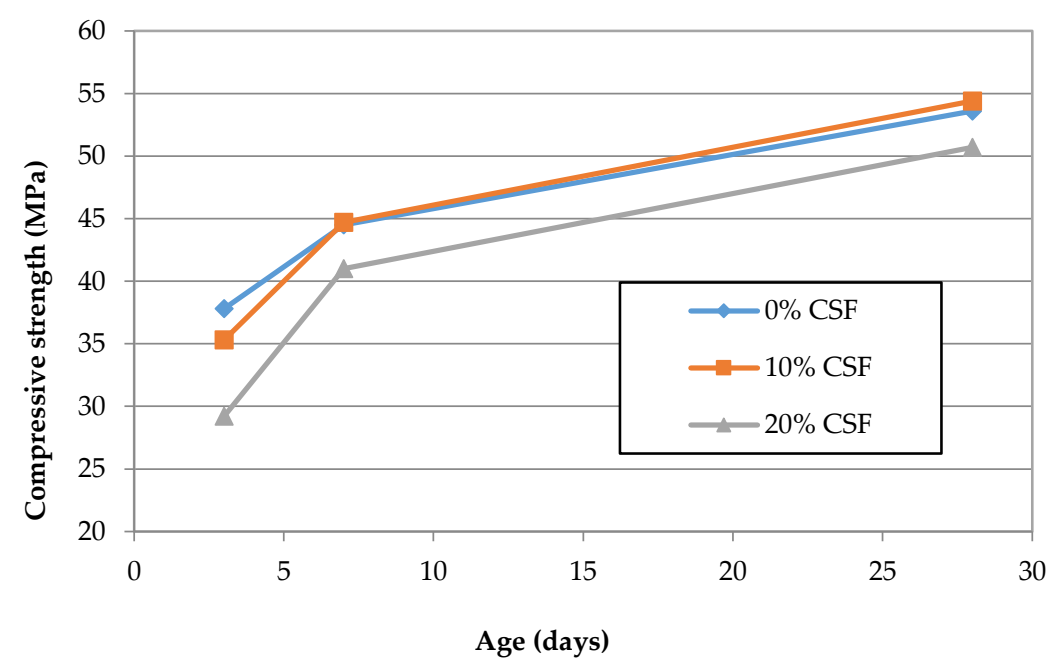

Figure 15. Compressive strength development of mortars. 


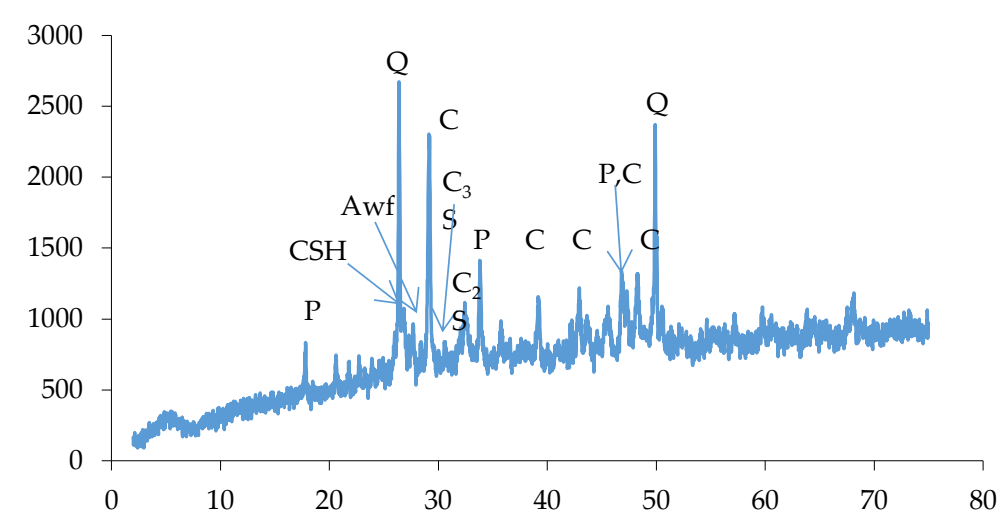

Figure 16. XRD diagram of cement mortar with $80 \%$ cement and $20 \%$ CSF, where C: calcite, P: portladite, Q: quartz, Awf: Awfillite, CSH: hydrated cement.

The decrease of compressive strength when $20 \%$ CSF was added can be related to the calcite content of CSF and its behavior as filler. Similar results have been observed by Nehdi et al. when limestone filler was used for cement substitution in mortars [41]. The porosity of mortar with $10 \%$ CSF was $6.6 \%$ and of mortar with $20 \%$ CSF was $10.3 \%$, showing an increase compared to the reference mortar with no CSF inclusion, which had $3.5 \%$ porosity. This increase can be attributed to the porous nature of the hydrated cement mortar present in CSF, in a similar manner to the porous nature of fine recycled aggregates.

\subsubsection{CSF for Soil Stabilization}

The soil used as a reference had the chemical composition shown in Table 6, while its Atterberg limits were as follows: liquid limit LL: 56, plastic limit PL: 29.4 and plasticity Index PI: 26.6. Overall, it was categorized as poor for subgrade. Figure 17 shows the dry density versus moisture content for soil with $0 \%, 10 \%$ and $20 \%$ soil addition. As shown in Table 7 , the dry density increased as the CSF rate increased while the required moisture in order to reach the maximum dry density reduced. Both of these properties are desirable for soil stabilization, but the most significant increase is that of the load-bearing capacity of soils, expressed by the CBR value. Furthermore, a higher percentage of CSF increased the CBR value even more. A similar strength increase has been reported (at lower addition percentages) when using lime for soil improvement [42,43].

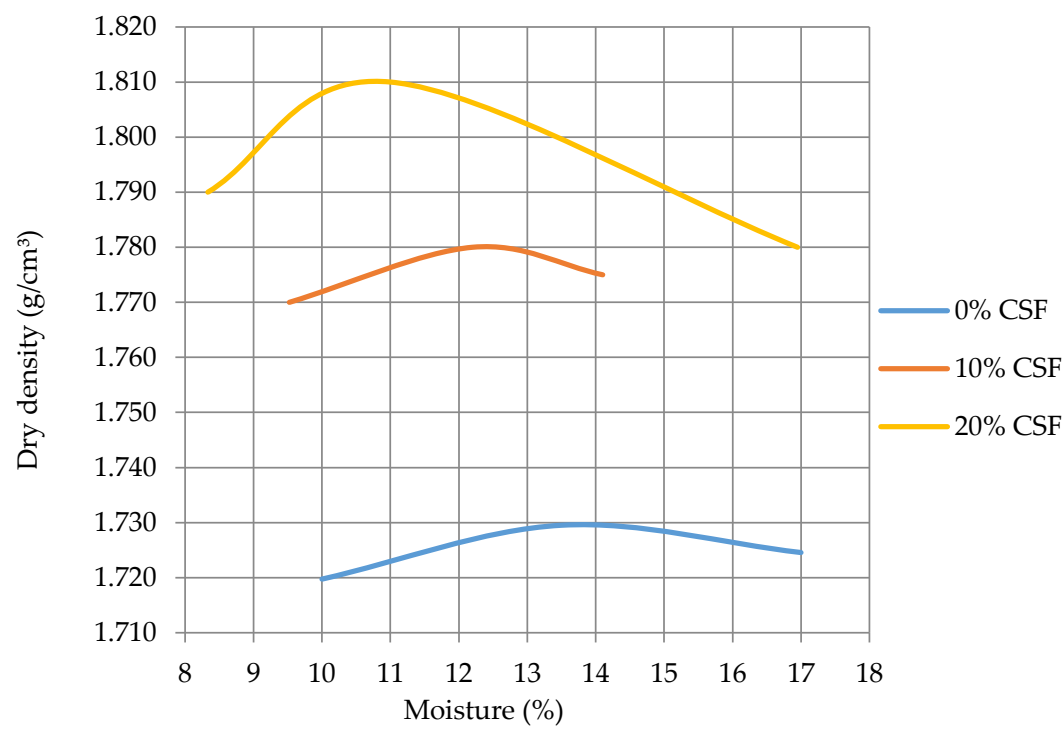

Figure 17. Dry density versus moisture content for soil stabilized with various CSF additions. 
Table 7. Soil stabilization test results.

\begin{tabular}{lccc}
\hline & 0\% CSF & 10\% CSF & 20\% CSF \\
\hline Maximum dry density $\left(\mathrm{g} / \mathrm{cm}^{3}\right)$ & 1.73 & 1.78 & 1.81 \\
Optimum moisture content $(\%)$ & 14.0 & 12.4 & 10.6 \\
CBR $(\%)$ & 5 & 12 & 33 \\
\hline
\end{tabular}

The considerable increase in the CBR value of the soil treated with CSF implies that it can serve as a potential soil stabilization material, provided that it is primarily tested for micropollutants. The higher addition rate required compared to other possible additions (lime, cement) is not a great disadvantage, as CSF is a low-value industrial by-product. Also, Figure 17 shows that that soil with $20 \%$ CSF addition was more sensitive to water variation compared to soil without CSF, which needs to be taken account at the design stage.

\section{Conclusions}

The main conclusions drawn from the research can be summarized as follows:

- The properties of the recycled aggregates produced within a single RMC plant vary greatly, despite the fact that they are recycled concrete aggregates, without any mixed construction materials. Therefore, they should be managed separately and directed to suitable applications;

- All three recycled aggregates tested can be potentially be used in construction applications, after simple processing (crushing, sieving and pre-soaking), indicating that they do not require the energy and cost for transportation outside the RMC plant;

- $\quad$ The recycled aggregates from hardened concrete specimens (HR) had better properties compared to recycled aggregates from concrete returns (CR) and the use of their fine fraction could also be considered for structural concrete production;

- The durability properties of concrete with HR and CR were slightly reduced when $100 \%$ of the coarse fraction was used and considerably reduced when $100 \%$ of the fine and coarse fraction was used. Future research could determine the optimum amount of natural aggregate replacement, as in all recycled aggregates;

- CSF seems to be a good-quality fine material, provided that it is crushed and sieved through the $75 \mu \mathrm{m}$ sieve;

- CSF could potentially be used as a filler material in cement mortar production and as an additive for soil stabilization.

Author Contributions: Conceptualization, E.A. and M.P.; methodology, E.A.; validation, M.P. and E.-C.T.; formal analysis, E.-C.T.; investigation, D.A. and K.Z.; data curation, M.P., D.A., K.Z. and E.-C.T.; writing-original draft preparation, E.A. and M.P.; writing - review and editing, E.A.Funding: This research received no external funding.

Acknowledgments: The authors would like to thank G. Moraitis and Interbeton S.A. for their assistance in providing information and materials for the present research.

Conflicts of Interest: The authors declare no conflict of interest.

\section{References}

1. Behera, M.; Bhattacharyya, S.K.; Minocha, A.K.; Deoliya, R.; Maiti, S. Recycled aggregate from C\&D waste \& its use in concrete-A breakthrough towards sustainability in construction sector: A review. Constr. Build. Mater. 2014, 68, 501-516. [CrossRef]

2. European Ready Mixed Concrete Organization. Ready-Mixed Concrete Industry Statistics-Year 2016. Available online: http:/ / ermco.eu/new/wp-content/uploads/2018/07 /ERMCO-Statistics-2016-18.02.04. pdf (accessed on 28 September 2018). 
3. Sealey, B.J.; Hill, G.J.; Phillips, P.S. Review of Strategy for Recycling and Reuse of Waste Materials. In Recycling and Reuse of Sewage Sludge, Proceedings of the International Symposium Organised by the Concrete Technology Unit and Held at the University of Dundee, Scotland, UK, 19-20 March 2001; Dhir, R.K., Limbachiya, M.K., McCarthy, M.J., Eds.; Thomas Telford: London, UK, 2001; pp. 325-336.

4. Vieira, L.D.B.P.; de Figueiredo, A.D. Evaluation of concrete recycling system efficiency for ready-mix concrete plants. Waste Manag. 2016, 56, 337-351. [CrossRef] [PubMed]

5. Xuan, D.; Poon, C.S.; Zheng, W. Management and sustainable utilization of processing wastes from ready-mixed concrete plants in construction: A review. Resour. Conserv. Recycl. 2018, 136, 238-247. [CrossRef]

6. Xuan, D.; Zhan, B.; Poon, C.S.; Zheng, W. Innovative reuse of concrete slurry waste from ready-mixed concrete plants in construction products. J. Hazard. Mater. 2016, 312, 65-72. [CrossRef] [PubMed]

7. Pedro, D.; De Brito, J.; Evangelista, L. Influence of the use of recycled concrete aggregates from different sources on structural concrete. Constr. Build. Mater. 2014, 71, 141-151. [CrossRef]

8. Kou, S.C.; Zhan, B.J.; Poon, C.S. Feasibility study of using recycled fresh concrete waste as coarse aggregates in concrete. Constr. Build. Mater. 2012, 28, 549-556. [CrossRef]

9. Audo, M.; Mahieux, P.Y.; Turcry, P. Utilization of sludge from ready-mixed concrete plants as a substitute for limestone fillers. Constr. Build. Mater. 2016, 112, 790-799. [CrossRef]

10. Poon, C.S.; Chan, D. The use of recycled aggregate in concrete in Hong Kong. Resour. Conserv. Recycl. 2007, 50, 293-305. [CrossRef]

11. Rao, A.; Jha, K.N.; Misra, S. Use of aggregates from recycled construction and demolition waste in concrete. Resour. Conserv. Recycl. 2007, 50, 71-81. [CrossRef]

12. Yehia, S.; Abdelfatah, A. Examining the Variability of Recycled Concrete Aggregate Properties. In Proceedings of the International Conference on Civil, Architecture and Sustainable Development (CASD-2016), London, UK, 1-2 December 2016; pp. 57-60.

13. Katz, A. Properties of concrete made with recycled aggregate from partially hydrated old concrete. Cem. Concr. Res. 2003, 33, 703-711. [CrossRef]

14. Rahal, K. Mechanical properties of concrete with recycled coarse aggregate. Build. Environ. 2007, 42, 407-415. [CrossRef]

15. Sagoe-Crentsil, K.K.; Brown, T.; Taylor, A.H. Performance of concrete made with commercially produced coarse recycled concrete aggregate. Cem. Concr. Res. 2001, 31, 707-712. [CrossRef]

16. Poon, C.S.; Shui, Z.H.; Lam, L. Effect of microstructure of ITZ on compressive strength of concrete prepared with recycled aggregates. Constr. Build. Mater. 2004, 18, 461-468. [CrossRef]

17. Shi, C.; Li, Y.; Zhang, J.; Li, W.; Chong, L.; Xie, Z. Performance enhancement of recycled concrete aggregate-A review. J. Clean. Prod. 2016, 112, 466-472. [CrossRef]

18. De Juan, M.S.; Gutiérrez, P.A. Study on the influence of attached mortar content on the properties of recycled concrete aggregate. Constr. Build. Mater. 2009, 23, 872-877. [CrossRef]

19. Dimitriou, G.; Savva, P.; Petrou, M.F. Enhancing mechanical and durability properties of recycled aggregate concrete. Constr. Build. Mater. 2018, 158, 228-235. [CrossRef]

20. Pepe, M.; Toledo Filho, R.D.; Koenders, E.A.; Martinelli, E. Alternative processing procedures for recycled aggregates in structural concrete. Constr. Build. Mater. 2014, 69, 124-132. [CrossRef]

21. Silva, R.V.; De Brito, J.; Dhir, R.K. Availability and processing of recycled aggregates within the construction and demolition supply chain: A review. J. Clean. Prod. 2017, 143, 598-614. [CrossRef]

22. Oikonomou, N.D. Recycled concrete aggregates. Cem. Concr. Compos. 2005, 27, 315-318. [CrossRef]

23. Agrela, F.; De Juan, M.S.; Ayuso, J.; Geraldes, V.L.; Jiménez, J.R. Limiting properties in the characterisation of mixed recycled aggregates for use in the manufacture of concrete. Constr. Build. Mater. 2011, 25, 3950-3955. [CrossRef]

24. Padmini, A.K.; Ramamurthy, K.; Mathews, M.S. Influence of parent concrete on the properties of recycled aggregate concrete. Constr. Build. Mater. 2009, 23, 829-836. [CrossRef]

25. Yang, K.H.; Chung, H.S.; Ashour, A. Influence of type and replacement level of recycled aggregates on concrete properties. ACI Mater. J. 2008, 3, 289-296. [CrossRef]

26. Audo, M.; Mahieux, P.Y.; Turcry, P.; Chateau, L.; Churlaud, C. Characterization of ready-mixed concrete plants sludge and incorporation into mortars: Origin of pollutants, environmental characterization and impacts on mortars characteristics. J. Clean. Prod. 2018, 183, 153-161. [CrossRef] 
27. Chini, S.A.; Mbwambo, W.J. Environmentally friendly solutions for the disposal of concrete wash water from ready mixed concrete operations. In Proceedings of the CIB W89 Beijing International Conference, Beijing, China, 21-24 October 1996; pp. 21-24.

28. Mashaly, A.O.; El-Kaliouby, B.A.; Shalaby, B.N.; El-Gohary, A.M.; Rashwan, M.A. Effects of marble sludge incorporation on the properties of cement composites and concrete paving blocks. J. Clean. Prod. 2016, 112, 731-741. [CrossRef]

29. Galetakis, M.; Soultana, A. A review on the utilisation of quarry and ornamental stone industry fine by-products in the construction sector. Constr. Build. Mater. 2016, 102, 769-781. [CrossRef]

30. Cardoso, R.; Silva, R.V.; de Brito, J.; Dhir, R. Use of recycled aggregates from construction and demolition waste in geotechnical applications: A literature review. Waste Manag. 2016, 49, 131-145. [CrossRef] [PubMed]

31. De Brito, J.; Saikia, N. Recycled Aggregate in Concrete: Use of Industrial, Construction and Demolition Waste; Springer: London, UK, 2012; ISBN 9781447145394.

32. Kazaz, A.; Ulubeyli, S.; Er, B.; Arslan, V.; Atici, M.; Arslan, A. Fresh ready-mixed concrete waste in construction projects: A planning approach. Organ. Technol. Manag. Constr. Int. J. 2015, 7, 1280-1288. [CrossRef]

33. Ferreira, L.; De Brito, J.; Barra, M. Influence of the pre-saturation of recycled coarse concrete aggregates on concrete properties. Mag. Concr. Res. 2011, 63, 617-627. [CrossRef]

34. Zhao, Z.; Remond, S.; Damidot, D.; Xu, W. Influence of fine recycled concrete aggregates on the properties of mortars. Constr. Build. Mater. 2015, 81, 179-186. [CrossRef]

35. Evangelista, L.; Guedes, M.; De Brito, J.; Ferro, A.C.; Pereira, M.F. Physical, chemical and mineralogical properties of fine recycled aggregates made from concrete waste. Constr. Build. Mater. 2015, 86, 178-188. [CrossRef]

36. Khatib, J.M. Properties of concrete incorporating fine recycled aggregate. Cem. Concr. Res. 2005, 35, 763-769. [CrossRef]

37. Etxeberria, M.; Vázquez, E.; Marí, A.; Barra, M. Influence of amount of recycled coarse aggregates and production process on properties of recycled aggregate concrete. Cem. Concr. Res. 2007, 37, 735-742. [CrossRef]

38. Evangelista, L.; De Brito, J. Mechanical behaviour of concrete made with fine recycled concrete aggregates. Cem. Concr. Compos. 2007, 29, 397-401. [CrossRef]

39. Berodier, E.; Scrivener, K. Understanding the Filler Effect on the Nucleation and Growth of C-S-H. J. Am. Ceram. Soc. 2014, 97, 3764-3773. [CrossRef]

40. De Weerdt, K.; Haha, M.B.; Le Saout, G.; Kjellsen, K.O.; Justnes, H.; Lothenbach, B. Hydration mechanisms of ternary Portland cements containing limestone powder and fly ash. Cem. Concr. Res. 2011, 41, 279-291. [CrossRef]

41. Nehdi, M.; Mindess, S.; Aitcin, P.C. Optimization of high strength limestone filler cement mortars. Cem. Concr. Res. 1996, 26, 883-893. [CrossRef]

42. Manasseh, J.; Olufemi, A.I. Effect of lime on some geotechnical properties of Igumale shale. Electron. J. Geotech. Eng. 2008, 13, 1-12.

43. Amu, O.O.; Fajobi, A.B.; Oke, B.O. Effect of eggshell powder on the stabilizing potential of lime on an expansive clay soil. J. Appl. Sci. 2005, 5, 1474-1478. [CrossRef]

(C) 2018 by the authors. Licensee MDPI, Basel, Switzerland. This article is an open access article distributed under the terms and conditions of the Creative Commons Attribution (CC BY) license (http://creativecommons.org/licenses/by/4.0/). 